\title{
Antioxidant, Some Flavor Components, Microbiological and Microstructure Characteristics of Corn Milk Yoghurt
}

\author{
Ateteallah Hassan Ateteallah'1, Amna Abul-Kasem Abbas Osman² \\ ${ }^{1}$ Dairy Science Department, Faculty of Agriculture, Sohag University, Sohag, Egypt \\ ${ }^{2}$ Food Science and Nutrition Department, Faculty of Agriculture, Sohag University, Sohag, Egypt \\ Email: ateteallah@yahoo.com
}

How to cite this paper: Ateteallah, A.H. and Osman, A.A.-K.A. (2019) Antioxidant, Some Flavor Components, Microbiological and Microstructure Characteristics of Corn Milk Yoghurt. Food and $\mathrm{Nu}$ trition Sciences, 10, 551-560.

https://doi.org/10.4236/fns.2019.105040

Received: April 3, 2019

Accepted: May 24, 2019

Published: May 27, 2019

Copyright $\odot 2019$ by author(s) and Scientific Research Publishing Inc. This work is licensed under the Creative Commons Attribution International License (CC BY 4.0).

http://creativecommons.org/licenses/by/4.0/

\begin{abstract}
Corn milk is considered as a new innovation especially in the making of yoghurt based products. The present study was conducted to study antioxidants components such as (phenols compounds and DPPH scavenging activity), total volatile free fatty acids, microbiological and microstructure characteristics in yoghurt samples produced from two different ratios of buffalos and corn milk (70:30 coded A and 60:40 coded B) respectively. Results indicated that the increasing ratio of corn milk led to increase the content of phenolic components and DPPH scavenging activity. Total viable content decreased in samples (70:30 and 60:40). Streptococci and lactobacilli count decreased by the increase of corn milk in produced samples. Results also show that the trend of yeasts content was the opposite ones. Election microscopy examination revealed that adding corn milk to yoghurt had more smoothly and systematically distributed casein with a bit coarse structure less porosity in the network of casein. From these results could be concluded that adding $40 \%$ corn milk during processing of yoghurt is increasing the antioxidant activity and improves the microstructure as well.
\end{abstract}

\section{Keywords}

Corn Milk, Yoghurt, Antioxidant, Microstructure

\section{Introduction}

Yoghurt is one of the popular acceptable fermented dairy products. The nutritive value of yoghurt is based on the use of milk as the principal ingredient and subsequent changes that occur as a result of lactic acid fermentation. Corn (zee 
mays), a common staple tropical crop, is mainly starch with very low protein and the profile of the amino acid is poor [1]. Developing a new corn based product in the form of healthy yoghurt is an avenue to raise the awareness on corn consumption. Besides, the sweet taste of corn milk along with its aroma and balanced nutritional content is compared to other types of vegetable [2]. A good quality of raw corn milk can be obtained from milky stage of corn cob [3]. On one hand, Omueti and Ashye [4] reported that soy corn milk had higher acceptability and digestibility than soy milk for both of adults and children. Yoghurt produced by blend $30 \%$ corn milk with $70 \%$ buffalos milk and $40 \%$ corn milk with $60 \%$ buffalos milk had a high value of curd firmness compared to the yoghurt that produced from raw buffalos milk. On the other hand, these ratios had a good acceptability in flavor, body texture, appearance and color [5].

In recent years, there has been increasing interest in the use of natural food additives into the diet. Epidemiological studies also show that fruit and vegetable consumption are associated with the reduced risk of several lifestyle related diseases such as cancer, cardiovascular disease (CVD) and stroke [6] [7] [8].

Processed sweet corn has high antioxidant activity. Also sweet corn has many of bioactive components i.e. lutein, frolic acid and phenol compounds [9] [10]. Nondairy additives like poly saccharides such as starches can be used in yoghurt in conjunction with dairy ingredients or on their own to modify the rheological properties [11]. [12] reported that using of modified starch in produced camel milk yoghurt increases water holding capacity and decreases synersis significantly. Also, microstructure of yogurt affected by the addition, the microstructure was dense and smoother than control samples. Unfortunately, there is no enough data reported dealing with the determination of the nutritional value such as antioxidant components, microbiological characteristics and microstructure of yoghurt produced from buffalos and corn milk.

The objective of study was to evaluate the nutritive value, bioactive component, microstructure and microbiological quality of yoghurt produced from buffalo's milk and corn milk yoghurt.

\section{Materials and Methods}

\subsection{Materials}

Morning raw buffalo's milk was obtained from faculty of agriculture, Sohag University.

Corn milk: was obtained from sohag governorate by harvest white cob corn grains at milky stage of maturity when grains most juicy and milky. Then the grains were separated and mixed with water in ratio $1: 2(\mathrm{w} \backslash \mathrm{w})$ using blender. Finally the mixture was filtered through cheese cloth.

\subsection{Manufacture of Buffalos Corn Milk Yogurt}

Buffalos milk was add to corn milk at tow ratios, the first ratio $70 \%$ buffalo milk: $30 \%$ Corn milk and the second ratio $60 \%$ buffalo milk: $40 \%$ corn milk. The mix- 
tures were pasteurized to $75^{\circ} \mathrm{C}$ for 15 second, and then cooled to $40^{\circ} \mathrm{C}$, the milk was inoculated with $1.5 \%$ of starter that obtained from chr. Hansen (Streptococcus thermophiles and Lactobacillus delbruckii sup sp. bulgaricus). The cups were incubated at $40^{\circ} \mathrm{C}$ until coagulation and stored at $5^{\circ} \mathrm{C}$. The selected different ratios amid to selection the best ratio in producing a good quality yoghurt as regard to the accessibility, low cost and highly nutritional value [5]. Samples analyzed as fresh after $24 \mathrm{~h}$ and periodically during storage period for $14 \mathrm{~d}$. All experiments were carried out in triplicate.

\subsection{Chemical Analysis}

\subsubsection{Total Phenolic Assay}

Total phenolic compounds were determined by an assay modified from Shetty [13].

\subsubsection{DPPH Free Radicals Scavenging Activity}

The ability of the extracts to scavenge 1,1-diphenyl-2-picrylhydrazyl (DPPH) free radicals was determined by the method described by Molyneux [14].

\subsubsection{Determination of Flavor Components}

Total components were qualified by determination of total volatile free fatty acids (TVFFA) using the method described by Kosikowski [15].

\subsubsection{Microbiological Analyses}

Total Microbial Count (TC) was determined according to Marshall [16]. Lactic acied bacteria were counted on streptococci and Lactobacilli medium as described by IDF [17]. Yeasts and molds were carried out by IDF [18] using malt extract agar medium.

\subsection{Scanning Electron Microscopy (SEM)}

The scanning electron microscopy was prepared as described by Khalifa and Ibrahim [12] in National Research Center, Giza, Egypt.

\subsection{Statistical Analysis}

Data was analyzed to compare means by repeated measurements analysis within treatment and storage periods using SPSS vesion 11.5.06 sep, 2002. SPSS Inc., 1999-2002.

\section{Results and Discussion}

\subsection{Total Phenolic Content (TPC)}

The total phenolic content (TPC) of buffalo and corn milk was $2.10 \pm 0.26$ and $7.07 \pm 0.66 \mathrm{mg} \mathrm{GAE} / 100 \mathrm{~g}$ respectively. The TPC were significantly increased for all yogurt samples during refrigerated storage periods at $5^{\circ} \mathrm{C}$ as well as by increasing of replacement percentages. Control yogurt sample had the lowest value $3.46 \pm 0.36 \mathrm{mg} \mathrm{GAE} / 100 \mathrm{~g}$ where, buffalo and corn yogurt samples with a per- 
centage of replacement 60:40 respectively had the highest value $12.36 \pm 0.58 \mathrm{mg}$ GAE/100 $g$ at the end of storage time (Table 1). The increased TPC in yogurt samples during storage period can be explained by the presence of indigenous phytochemical compounds in corn milk (e.g., flavonoids and phenolic compounds). The amino acids like tyrosine has a phenolic side chain suggested led to an increasing in the TPC [19]. Another possibility is that microbial utilization of phenolic acids such as ferulic and $p$-coumaric acid during fermentation process and post acidification lead to the production of other phenolic acids such as vanillic and p-hydroxybenzoic acids before the aromatic ring structure is broken down [20].

\subsection{DPPH Scavenging Activity}

DPPH is a very stable organic free radical with a deep violet color which gives absorption in maxima within the $515-528 \mathrm{~nm}$ range. Upon receiving a proton from any hydrogen donor, mainly from phenolics, it loses its chromophore and becomes yellow [21]. The antioxidant activity of methanolic extracts of corn milk and yoghurt samples were detected where it were not in buffalo milk, adding of corn milk were influenced significantly on the antioxidant activity of yoghurt during the first day of storage, where DPPH scavenging activity of control sample was $13.31 \% \pm 1.45 \%$ it has slightly increased to $23.15 \% \pm 1.73 \%$ in buffalo and corn yogurt sample with a percentage of replacement 60:40 respectively, compared with the reference standards Ascorbic acid, BHT and Trolox it were $93.39 \pm 0.07,93.19 \pm 0.21$ and $84.82 \% \pm 0.21 \%$ respectively. The Inhibition of DPPH oxidations by each yoghurt samples were decreased with the progress of storage period (Table 2). Where it dramatically decreased in control sample was $3.04 \% \pm 0.28 \%$, it slightly decreased in buffalo and corn yoghurt sample with a percentage of replacement 60:40 respectively.

Highest DPPH inhibition during first days of storage may be attributed to the metabolically active yoghurt bacteria even at low temperature [22]. Continued microbial growth during refrigerated storage may have altered some of the phenolic compounds and hence their antioxidant activities [20]. The reduction in

Table 1. Total phenolic content of buffalo and corn milk, and its yogurts at different percentage of replacement during storage periods.

\begin{tabular}{cccc}
\hline Milk samples & \multicolumn{3}{c}{ Total phenols (mg/100 g) } \\
\hline Buffalos-milk & \multicolumn{3}{c}{$2.10 \pm 0.26$} \\
Corn-milk & \multicolumn{3}{c}{ Sto7 \pm 0.66} \\
\hline \multirow{3}{*}{ Yogurt samples } & 1 & 7 & 14 \\
\cline { 2 - 4 } & $3.46 \pm 0.36$ & $8.41 \pm 0.56$ & $10.15 \pm 0.56$ \\
Control & $3.65 \pm 0.17$ & $9.63 \pm 0.86$ & $11.47 \pm 0.31$ \\
A & $4.71 \pm 0.23$ & $11.38 \pm 0.71$ & $12.36 \pm 0.58$ \\
B & \multicolumn{3}{c}{. }
\end{tabular}

Control $=100 \%$ buffalos milk, $\mathrm{A}=70 \%$ buffalo's milk: $30 \%$ corn milk, $\mathrm{B}=60 \%$ buffalo's milk: $40 \%$ corn milk. 
antioxidant activities during refrigerated storage of yogurt is attributed to increasing degradation of phenolic compounds with antioxidant activities [23] and/or increasing milk protein polyphenol interaction [24]. In this regard, the consumption of yoghurt is highly advisable within 7 days after yoghurt-making to benefit from high live bacterial contents [25] and high antioxidant activities useful for protective cardiovascular effect [26].

\subsection{Total Volatile Free Fatty Acids}

Total volatile free fatty acids was determined as flavor components reported to be presented in yoghurt and zeer milk [27] [28]. Total volatile free fatty acids as $\mathrm{mL}$ $0.1 \mathrm{~N} \mathrm{NaOH} / 100$ g decreased with increasing corn milk ratio Table 3. TVFFA Control samples were the highest compared with corn milk yoghurt and reached $1.4 \mathrm{~mL} 0.1 \mathrm{~N} \mathrm{NaOH}$ at 14 day storage. The lowest value was $0.6 \mathrm{~mL} 0.1 \mathrm{~N} \mathrm{NaOH}$ on fresh corn milk yoghurt. From the presented data in Table 3 the values of

Table 2. DPPH scavenging activity of buffalo and corn milk, and its yogurts at different percentage of replacement during storage periods.

\begin{tabular}{|c|c|c|c|}
\hline Milk samples & \multicolumn{3}{|c|}{ DPPH scavenging activity (\%) } \\
\hline Buffalos-milk & \multicolumn{3}{|c|}{ ND } \\
\hline Corn-milk & \multicolumn{3}{|c|}{$34.22 \pm 1.06$} \\
\hline \multirow[b]{2}{*}{ Yogurt samples } & \multicolumn{3}{|c|}{ Storage period (days) } \\
\hline & 1 & 7 & 14 \\
\hline Control & $13.31 \pm 1.45$ & $10.99 \pm 1.77$ & $3.04 \pm 0.28$ \\
\hline A & $19.03 \pm 0.87$ & $20.00 \pm 0.65$ & $12.08 \pm 0.20$ \\
\hline $\mathrm{B}$ & $23.15 \pm 1.73$ & $17.26 \pm 1.06$ & $15.20 \pm 0.77$ \\
\hline Ascorbic acid $(1 \mathrm{mg} / \mathrm{ml})$ & $93.39 \pm 0.07$ & & \\
\hline BHT (1 mg/ml) & $93.19 \pm 0.21$ & & \\
\hline Trolox $(1 \mathrm{mg} / \mathrm{ml})$ & $84.82 \pm 0.21$ & & \\
\hline
\end{tabular}

Control $=100 \%$ buffalos milk, $A=70 \%$ buffalo's milk: $30 \%$ corn milk, $\mathrm{B}=60 \%$ buffalo's milk: $40 \%$ corn milk ND = not detected.

Table 3. Total volatile of yoghurt made from buffalos two ratios of corn milk during storage.

\begin{tabular}{ccc}
\hline Treatments & Storage period day & TVFFA $\mathrm{mL} 0.1 \mathrm{~N} \mathrm{NaOH}$ \\
\hline \multirow{3}{*}{ Control } & Fresh & 0.9 \\
& 7 day & 1.1 \\
& 14 day & 1.4 \\
& Fresh & 0.7 \\
A & 7 day & 0.8 \\
& Fresh day & 1.2 \\
& 7 day & 0.6 \\
B & 14 day & 0.7 \\
& & 0.8 \\
\hline
\end{tabular}

Control $=100 \%$ buffalos milk, $A=70 \%$ buffalo's milk: $30 \%$ corn milk, $B=60 \%$ buffalo's milk: $40 \%$ corn milk. 
TVFFA are very low than those found in zabady by Abou-Donia [29]. The decrease of TVFFA seems related to the how fat content of corn milk yoghurt.

\subsection{Microbiological Analysis}

Microbiological properties of yoghurt which was made from raw buffalo's milk and buffalos-corn milk are shown in Table 4 . The total viable count decreased in the treatment $\mathrm{A}$ and $\mathrm{B}$ compared control. This finding may be due to decrease the total volatile free fatty acids in treatment $\mathrm{A}$ and $\mathrm{B}$, these results are in agreement with that reported by Abou Ayana and Gamal El Deen [30].

On the other hand total viable count decreased significantly $(\mathrm{P}<0.05)$ during storage periods (7 and 14 day) of control, A and B (log $9.75 \mathrm{cfu} / \mathrm{g}, \log 9.70 \mathrm{cfu} / \mathrm{g}$ and $\log 9.71 \mathrm{cfu} / \mathrm{g}),(\log 9.54 \mathrm{cfu} / \mathrm{g}, \log 9.08 \mathrm{cfu} / \mathrm{g}$ and $\log 9.079 \mathrm{cfu} / \mathrm{g})$ and $(\log$ $9.54 \mathrm{cfu} / \mathrm{g}, \log 9.38 \mathrm{cfu} / \mathrm{g}$ and $\log 9.079 \mathrm{cfu} / \mathrm{g}$ ) respectively. Streptococcus count in fresh control $\log 9.45 \mathrm{cfu} / \mathrm{g}$ was observed to be higher than that of A and B treatment $\log 9.35 \mathrm{cfu} / \mathrm{g}$ and $\log 9.33 \mathrm{cfu} / \mathrm{g}$ respectively. Throughout the storage period the numbers of lactobacillus spp. in fresh control, A and B treatment had lower number $\log 7.95 \mathrm{cfu} / \mathrm{g}, \log 7.89 \mathrm{cfu} / \mathrm{g}$ and $\log 7,75 \mathrm{cfu} / \mathrm{g}$ respectively than that had by streptococcus $\log 9.45 \mathrm{cfu} / \mathrm{g}, \log 9.35 \mathrm{cfu} / \mathrm{g}$ and $\log 9.33 \mathrm{cfu} / \mathrm{g}$ respectively. Above results has agreement with that reported by Tamime and Robinson [31], the yoghurt should contain $10^{7}$ viable cells of lactic acid bacteria per $1 \mathrm{ml} / \mathrm{L}$. All the fresh treatment control, A and B showed low count of yeast log 2.85 $\mathrm{cfu} / \mathrm{g}, \log 2.70 \mathrm{cfu} / \mathrm{g}$ and $\log 2.30 \mathrm{cfu} / \mathrm{g}$ respectively. This finding was agreement with Makanjuola [32] who found that $\log 2.29 \mathrm{cuf} / \mathrm{g}$ for soy corn yoghurt $(80 \%$ soy: $20 \%$ corn). Yeasts and molds were significantly $(\mathrm{p}<0.05)$ increased with increase storage time with maximum value $\log 4.48 \mathrm{cfu} / \mathrm{g}$ for control, log 4.78 $\mathrm{Cfu} / \mathrm{g}$ for treatment $\mathrm{A}$ and $\log 4.85 \mathrm{cfu} / \mathrm{g}$ for treatment B at 14 day. Dardashti [33] reported that contamination by molds and yeast in traditional processed yoghurt.

Table 4. Total, streptococci, lactobacilli and yeasts count of yoghurt made from buffalos milk and tow levels of corn milk.

\begin{tabular}{cccccc}
\hline Treatments & Storage period day & $\begin{array}{c}\text { Total count } \\
\text { Log cfu/g }\end{array}$ & $\begin{array}{c}\text { streptococcus } \\
\text { Log cfu/g }\end{array}$ & lactobacillus Log cfu/g & $\begin{array}{c}\text { Yeast } \\
\text { Log cfu/g }\end{array}$ \\
\hline \multirow{3}{*}{ Control } & Fresh & 9.75 & 9.45 & 7.95 & 2.85 \\
& 7 day & 9.70 & 9.03 & 7.74 & 3.41 \\
& 14 day & 9.71 & 9.01 & 8.23 & 4.48 \\
& Fresh & 9.54 & 9.35 & 7.89 & 2.70 \\
A & 7 day & 9.08 & 8.99 & 7.78 & 3.44 \\
& 14 day & 9.08 & 7.65 & 7.50 & 4.78 \\
& Fresh & 9.54 & 9.33 & 7.75 & 2.30 \\
& 7 day & 9.38 & 9.00 & 7.68 & 3.66 \\
& 14 day & 9.08 & 7.60 & 7.48 & 4.85 \\
\hline
\end{tabular}

Control $=100 \%$ buffalos milk, $A=70 \%$ buffalo's milk: $30 \%$ corn milk, $B=60 \%$ buffalo's milk: $40 \%$ corn milk. 


\subsection{Microstructure}

The microstructure of buffalos-corn milk yoghurt as affected by the addition of corn milk ratios are demonstrated in Figure 1. Microstructure analysis illustrated that the internal structure of buffalos-corn (A and B) yoghurt was smoother and denser than the surface of control sample Figure 1. The control buffalo's milk yoghurt showed rough and granular outer surfaces by comparison the buffalos-corn milk yoghurt (A and B) that had smoother and denser structure. This structure may be due to the texture attributes of product. Add corn milk to yoghurt had more smoothly and systematically distributed casein with a

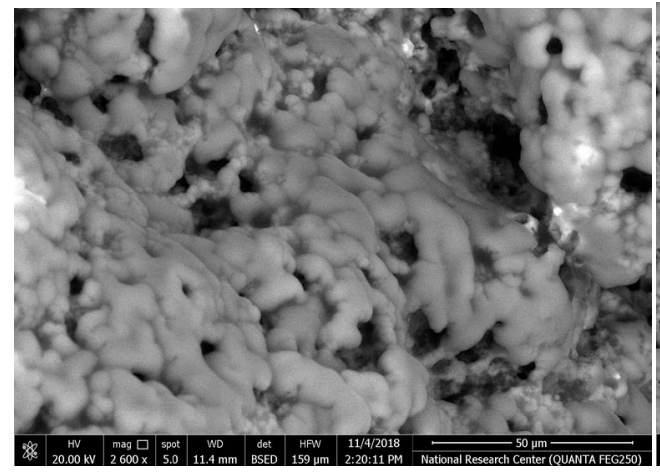

control $100 \mu \mathrm{m}$

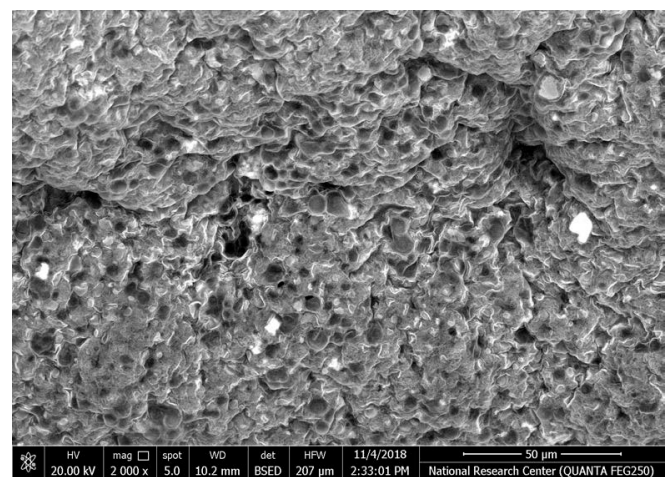

A $100 \mu \mathrm{m}$

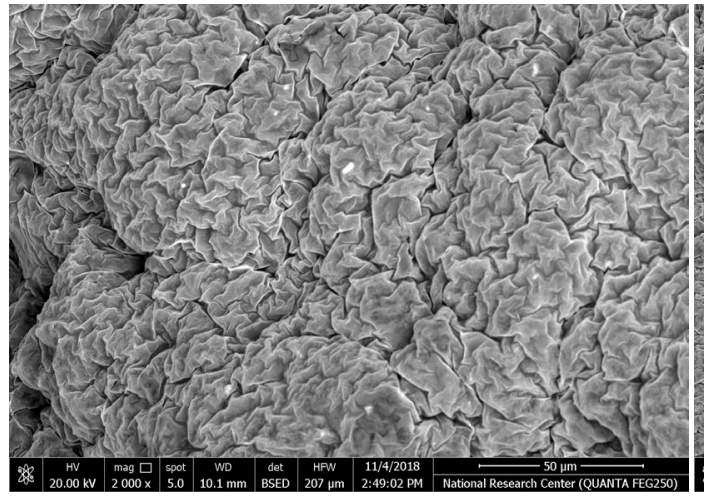

B $100 \mu \mathrm{m}$

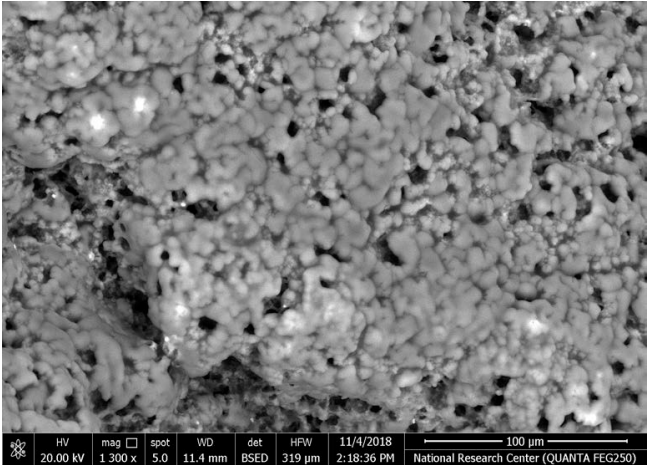

control $50 \mu \mathrm{m}$

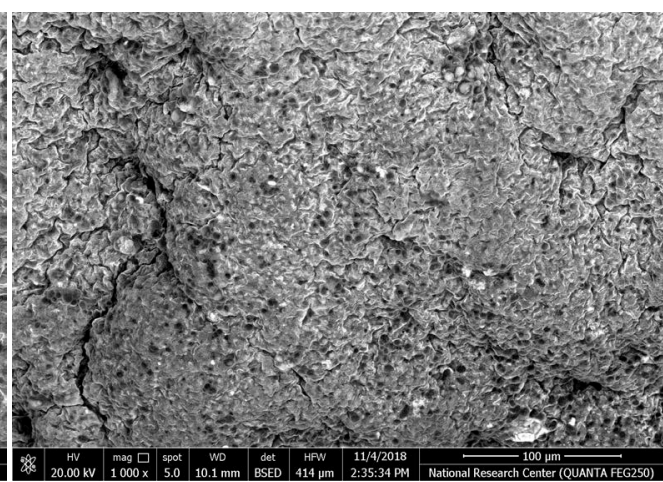

A $50 \mu \mathrm{m}$

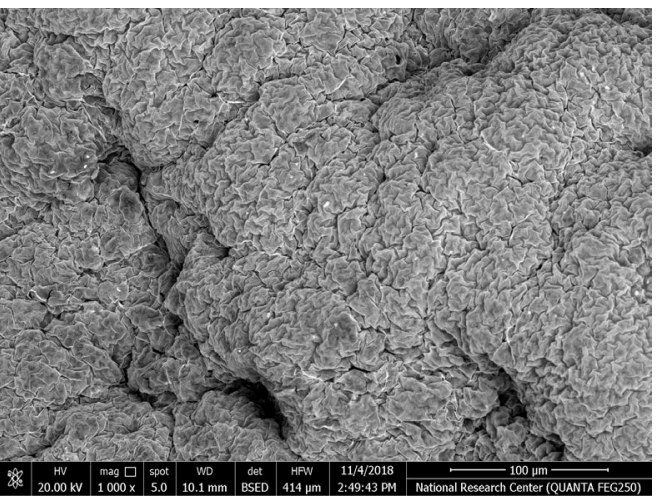

B $50 \mu \mathrm{m}$

Control $=100 \%$ buffalos milk, $A=70 \%$ buffalo's milk: $30 \%$ corn milk, $B=60 \%$ buffalo's milk: $40 \%$ corn milk.

Figure 1. Microstructure of buffalos and buffalos-corn milk yoghurt. 
bit coarse structure, also less porosity in the network of casein. This may be attributed to emulsion and hydrocolloids stability catalyzed cross-link formation between milk proteins as demonstrated by Lorenzen [34]. Also this finding has agreement with Kalifa and Ibrahim [12] they found the same effect when add modified starches to camel's milk yoghurt. On other hand Figure 1 shown that increase the ratio of corn milk in yoghurt from $30 \%$ to $40 \%$ makes the structure more smooth, dense and homogenous. Finally addition corn milk to buffalos-corn yoghurt improved the texture of yoghurt which has agreement with Ibrahim [5] they reported that addition of corn milk to buffalos-corn yoghurt improved texture body due to high cured firmness.

\section{Conclusion}

The present study concluded that adding corn milk during processing of yoghurt by blend $30 \%$ corn milk with $70 \%$ buffalos milk and $40 \%$ corn milk with $60 \%$ buffalos milk added value to the produced yoghurt through in-creased nutrient content, content of phenolic components and antioxidant activity, also improved the microstructure through in-creased smooth, dense and homogenous.

\section{Conflicts of Interest}

The authors declare no conflicts of interest regarding the publication of this paper.

\section{References}

[1] Ajala, L., Ologunde, M.O. and Adetuji, F.O. (2013) Physicochemical and Sensory Qualities of Speciced Soy-Corn Milk. African Journal of Biotechnology, 12, 2262-2265. https://doi.org/10.5897/AJB12.1629

[2] Supavititvana, P., Wirjantoro, T.I., Apichartsrangkoon, A. and Raviyan, P. (2008) Addition of Gelatin Enhanced Gelation of Corn Milk Yoghurt. Food Chemistry, 106, 211-216. https://doi.org/10.1016/j.foodchem.2007.05.058

[3] Trisnawati, C.Y., Srianta, I. and Marsono, Y. (2013) Effect of Corn Varieties on the Characteristics of Soy Corn Milk. International Food Research Journal, 20, 1187-1190.

[4] Omueti, O. and Ashaye, A. (1998) Home-Level Preparation, Nutrient Content and Acceptability of Soy-Corn Milk. In: Chainuvati, C. and Sarobol, N.P., Eds., Proceedings of the World Soybean Research Conference, Kasetsart University, Bangkok, 579-583.

[5] Ibrahim, F.S., Ateteallah, A.H., Abd El-aal, H.A. and Khalil, O.S.F. (2019) Physicochemical and Organoleptic Characteristics of Manufactured Buffalo Milk Yoghurt Incorporated Soy and Corn Milks. Food and Nutrition Sciences, 10, 28-36. https://doi.org/10.4236/fns.2019.101003

[6] Block, G., Patterson, B. and Subar, A. (1992) Fruit, Vegetables and Cancer Prevention: A Review of the Epidemiological Evidence. Nutrition and Cancer, 18, 1-29. https://doi.org/10.1080/01635589209514201

[7] Ames, B.N., Shigenaga, M.K. and Hagen, T.M. (1993) Oxidants, Antioxidants, and the Degenerative Disease of Aging. Proceedings of the National Academy of 
Sciences of the United States of America, 90, 7915-7922. https://doi.org/10.1073/pnas.90.17.7915

[8] Ma, Q. and Kinner, K. (2002) Chemoprotection by Phenolic Antioxidants. Inhibition of Tumor Necrosis Factor Alpha Induction in Macrophages. The Journal of Biological Chemistry, 277, 2477-2484. https://doi.org/10.1074/jbc.M106685200

[9] Dewanto, V., Wu, X., Adom, K.K. and Liu, R.H. (2002) Thermal Processing Enhances the Nutritional Value of Tomatoes by Increasing Total Antioxidant Activity. Journal Agriculture Food Chemistry, 50, 3010-3014. https://doi.org/10.1021/jf0115589

[10] Kljak, K. and Gbesa, D. (2015) Carotenoid Content and Antioxidant Activity of Hexane Extracts from Selected Croatian Corn Hybrids. Food Chemistry, 167, 402-408. https://doi.org/10.1016/j.foodchem.2014.07.002

[11] Keogh, M.K. and O'Kennedy, B.T. (1998) Rheology of Stirred Yogurt as Affected by Added Milk Fat, Protein and Hydrocolloids. Journal of Food Science, 63, 108-112. https://doi.org/10.1111/j.1365-2621.1998.tb15687.x

[12] Khalifa, A.H. and Ibrahim, S.A. (2015) Influence of Addition Modified Starches as Stabilizer on Physicochemical and Textural Properties of Camel's Milk Yoghurt. Zagazig Journal of Food and Dairy Research, 42, 295-307.

[13] Shetty, K., Clydesdale, F. and Vattem, D. (2005) Clonal Screening and Sprout Based Bioprocessing of Phenolic Phytochemicals for Functional Foods. In: Shetty, K., Paliyath, G., Pometto, A. and Levin, R.E., Eds., Food Biotechnology, CRC Taylor \& Francis, New York, 603. https://doi.org/10.1201/9781420027976.ch2.02

[14] Molyneux, P. (2004) The Use of the Stable Free Radical Diphenylpicrylhydrazyl (DPPH) for Estimating Antioxidant Activity. Songklanakarin Journal Science Technology, 26, 211-219.

[15] Kosikowski, F.V. (1982) Cheese and Fermented Milk Foods. 3rd Edition, Edwards Brothers Inc., Ann Arbor, 153-167, 178.

[16] Marshall, R.T. (1992) Standard Methods for the Examination of Dairy Products. 16th Edition, American Public Health Association, Washington DC.

[17] IDF (1997) Yoghurt. Enumeration of Characteristic Microorganisms. Colony Count Technique at $37^{\circ} \mathrm{C}$. International Dairy Federation Standard 117B.

[18] IDF (1985) Milk and Milk Products. Detection and Enumeration of Yeasts and Moulds. International Dairy Federation Standard 94A.

[19] Shah, N.P. (2000) Effect of Milk-Derived Bioactives: An Overview. British Journal of Nutrition, 84, 3-10. https://doi.org/10.1017/S000711450000218X

[20] Blum, U. (1998) Effects of Microbial Utilization of Phenolic Acids and Their Phenolic Acid Breakdown Products on Allelpathic Interactions. Journal of Chemical Ecology, 24, 685-708. https://doi.org/10.1023/A:1022394203540

[21] Sultana, B., Anwar, F. and Przybylki, R. (2007) Antioxidants Potential of Corncob Extracts for Stabilization of Corn Oil Subjected to Microwave Heating. Food Chemistry, 104, 997-1005. https://doi.org/10.1016/j.foodchem.2006.12.061

[22] Papadimitriou, C.G., Mastrojiannaki, A.V., Silva, A.V., Gomes, A.M., Malcata, F.X. and Alichanidis, E. (2007) Identification of Peptides in Traditional and Probiotic Sheep Milk Yoghurt with Angiotensin I-Converting Enzyme (ACE)-Inhibitory Activity. Food Chemistry, 105, 647-656. https://doi.org/10.1016/j.foodchem.2007.04.028

[23] Yildiz, O. and Eyduran, S.P. (2009) Functional Components of Berry Fruits and Their Usage in Food Technologies. African Journal of Agricultural Research, 4, 
$422-426$

[24] Yuksel, Z., Avci, E. and Erdem, Y.K. (2010) Characterization of Binding Interactions between Green Tea Flavanoids and Milk Proteins. Food Chemistry, 121, 450-456. https://doi.org/10.1016/j.foodchem.2009.12.064

[25] Water, J.D., Keen, C.L. and Gershwin, M.E. (1999) The Influence of Chronic Yogurt Consumption on Immunity. Journal of Nutrition, 129, 1492S-1495S. https://doi.org/10.1093/jn/129.7.1492S

[26] Massey, L.K. (2001) Dairy Food Consumption, Blood Pressure and Stroke. Journal of Nutrition, 131, 1875-1878. https://doi.org/10.1093/jn/131.7.1875

[27] Abou-Donia, S.A. (1984) Egyptian Fresh Fermented Milk Product. New Zealand Journal of Dairy Science Technology, 19, 7-18.

[28] Ibrahim, F.S. (1991) Nutrient Contents, Proteolysis and Flavor Components of Concentrated Fermented Milk "Laban Zeer" Egyption. Journal of Applied Science, 6, 468-482.

[29] Abou-Donia, S.A., Sirry, I. and Abd El-Rahman, S.M. (1975) Chemical and Microbiological Studies on Kareish Cheese. Alexandria Journal Agriculture Research, 23, 243-243.

[30] Ayana, A. and El Deen, G. (2011) Improvement of the Properties of Goat's Milk Labneh Using Some Aromatic and Vegetable Oils. International Journal of Dairy Science, 6, 112-123. https://doi.org/10.3923/ijds.2011.112.123

[31] Tamime, A.Y. and Robinson, R.K. (1999) Yogurt Science and Technology. Woodhead Publishing Ltd., Cambridge.

[32] MaKanjuola, O.M. (2012) Production and Quality Evaluation of Soy Corn Yoghurt. Advanced Journal of Food Science and Technology, 4, 130-134.

[33] Dardashti, A.D., Afshin, A., Saeed, B., Grce, M., Pigac, J. and Mrsa, V. (2001) Study of Coliform, Yeast and Mold Contamination of Yoghurt in Ghaemshahr in Iran. Periodicum Biologorum, 103, 183-186.

[34] Lorenzen, P.C., Neve, H., Mautner, A. and Schlimme, E. (2002) Effect of Enzymatic Crosslinking of Milk Proteins on Functional Properties of Set-Style Yoghurt. International Journal Dairy Technology, 55, 152-157.

https://doi.org/10.1046/j.1471-0307.2002.00065.x 